\title{
The choice of Medicine as a profession and the students' labor perspective
}

\author{
Escolha da medicina como profissão e perspectiva laboral dos estudantes
}

\author{
Eduardo Delatorre Kamijo' ${ }^{10} \mid$ eduardokamijo@hotmail.com \\ Maria Victória Schweder de Lima' (D) mariavictoriaschwederdelima@hotmail.com \\ Ana Paula Pereira1 (D) ana.pereira@unoesc.edu.br \\ Elcio Luiz Bonamigo' ${ }^{1}$ elcio.bonamigo@unoesc.edu.br
}

\begin{abstract}
Introduction: Medicine is a prestigious profession, therefore, although competition for admission is fierce and studies require dedication and sacrifices, thousands of young people face the challenge of becoming doctors every year.

Objective: Describe the reasons why medical school students chose Medicine as a profession and their concerns about the job perspective.

Method: Quantitative descriptive and documentary research, through the application of a questionnaire with sociodemographic and specific questions.

Result: A high percentage of the female gender stood out, with $63.31 \%$ of the participants. The main reasons for choosing Medicine as a profession were altruism (71.75\%), financial stability (59.42\%) and personal accomplishment (58.77\%). However, there was a decrease in the preference for altruism during internship $(\mathrm{p}<0.01)$. The biggest concern after training was "Doing a good job / Being a good professional" $(79.87 \%)$ and, in relation to the "job market" and "devaluation of the profession", there was an increase in the concern during internship ( $p<0.001)$. The majority $(91.92 \%)$ expressed the intention to become a specialist physician, with the specialty of Gynecology and Obstetrics being the most sought after. Regarding the way of working, $51.3 \%$ expressed the desire to be a self-employed professional, $55.52 \%$ a public or private employee and $7.92 \%$ a liberal professional. The greatest difficulty expected in the profession was competition (57.70\%) and the most important requirement for professional practice was "Medicine as a means to be useful or help people" (98.38\%). Regarding the feelings experienced as a student, the levels of anxiety, stress and feeling of overload were high, respectively $80.52 \%, 79.55 \%$ and $73.38 \%$.

Conclusion: At the beginning of the course, there is a more idealized view of Medicine and throughout the development of phases, as contact with medical practice occurs, the students better understand their difficulties and increase their concerns, especially with the job market and the devaluation of the profession, causing, in some, the reduction of the humanistic ideals that motivated the choice of the profession, an aspect to be valued by medical schools during professional training.
\end{abstract}

Keywords: Medicine; Medical Students; Choice of Profession; Altruism.

\section{RESUMO}

Introdução: A medicina é uma profissão de prestígio, e, por isso, embora a concorrência para a admissão seja acirrada e os estudos exijam dedicação e sacrifícios, todos os anos milhares de jovens enfrentam o desafio de se tornarem médicos.

Objetivo: Este estudo teve como objetivo descrever as razões pelas quais os acadêmicos de um curso de Medicina escolheram a medicina como profissão e suas preocupações quanto à perspectiva laboral.

Método: Trata-se de uma pesquisa quantitativa, descritiva e documental, realizada por meio da aplicação de questionário com questões sociodemográficas e específicas.

Resultado: Destacou-se elevada percentagem do gênero feminino, com 63,31\% dos participantes. As principais razões de escolha da medicina como profissão foram altruísmo (71,75\%), estabilidade financeira (59,42\%) e realização pessoal (58,77\%). Entretanto, houve diminuição da preferência pelo altruísmo durante o internato $(p<0,01)$. A maior preocupação após a formação foi "realizar um bom trabalho/ser um bom profissional" $(79,87 \%), e$, em relação ao "mercado de trabalho" e à "desvalorização da profissão", verificou-se aumento da preocupação durante o internato ( $p<0,001)$. A maioria (91,92\%) manifestou a intenção de tornar-se médico especialista, sendo mais desejada a especialidade ginecologia e obstetrícia. Em relação à forma de trabalho, 51,3\% apontaram que gostariam de trabalhar como profissionais autônomos, 55,52\% manifestaram o desejo de ter um emprego público ou particular, e 7,92\% mencionaram a atuação como profissionais liberais. A maior dificuldade esperada na profissão foi a concorrência (57,70\%), e o requisito mais importante para o exercício profissional foi a "medicina como meio para ser útil ou ajudar pessoas" (98,38\%). Sobre os sentimentos experimentados como estudante, os níveis de ansiedade, estresse e sensação de sobrecarga foram elevados, respectivamente 80,52\%, 79,55\% e 73,38\%.

Conclusão: No início do curso, existe uma visão mais idealizada da medicina, e, no desenvolver das fases, conforme ocorre o contato com a prática médica, os acadêmicos percebem melhor as dificuldades e aumentam suas preocupações, sobretudo com o mercado de trabalho e a desvalorização da profissão, provocando, em alguns, a diminuição dos ideais humanísticos que motivaram a escolha da profissão, aspecto a ser valorizado pelas escolas de Medicina durante o ensino.

Palavras-chave: Medicina; Estudantes de Medicina; Escolha da Profissão; Altruísmo.

${ }^{1}$ Universidade do Oeste de Santa Catarina, Joaçaba, Santa Catarina, Brazil.

Chief Editor: Rosiane Viana Zuza Diniz. $\quad$ ～Associate Editor: Izabel Cristina Meister Martins Coelho.

Received on 03/09/21; Accepted on 09/28/21. | Evaluated by double blind review process. 


\section{INTRODUCTION}

Alleviating pain, curing diseases, saving lives and dedicating one's life to the benefit of others have been the pillars of the medical profession since its beginning; however, over the years and with the spread of other ideals, this science became more linked to economic issues than humanitarian ones ${ }^{1}$. The reflection of this growing financial interest supported the increase in the number of new medical schools throughout the Brazilian territory, and the opening of more vacancies in existing schools, which are adapted in places often without adequate structure for qualified education ${ }^{2}$.

A total of 357 medical schools were in operation in 2020, an index of 1.68 per million inhabitants, offering 45,337 openings with a competition rate of 23.19 , in a country that already has more than 500,000 doctors ${ }^{2}$. Taking this into account, questions are raised about the quality of medical training with the graduation of so many new professionals, an aspect that increases the concern of medical students.

Hippocrates recommended that physicians have natural abilities, culture, perseverance, dedication, willingness to study and work, aspects that already predicted the difficulties of the profession $^{3}$. Therefore, the medical course is seen as one of the most difficult ones to attend, as it requires intense dedication, sacrifices, as well as physical and emotional resistance from students ${ }^{4}$. However, every year, thousands of candidates face real battles in the university admission exams to become physicians.

The graduation in medicine covers both cognitive aspects and dedication to study, as it raises emotional issues intrinsic to the profession ${ }^{5}$. The medical students' stress is frequent and results from a series of factors such as extensive workload, lack of time for leisure and personal life, competitiveness throughout the course and direct contact with suffering that even contribute to a decline in their quality of life $^{6}$. The emergence of stress is more frequent at the beginning of the course, due to difficulties in adapting to the university rhythm and to the attended disciplines, in which theoreticalpractical activities predominate ${ }^{7}$.

A study aiming to raise the determining factors for choosing the medical course as a profession showed a high frequency of responses that mentioned the easy insertion in the labor market and good salaries ${ }^{8}$. On the other hand, although the prestige of the profession remains high, it seems there is some depreciation of the medical work in the health area and increased competition, arousing the concern of students 9 .

Therefore, studies that allow a greater understanding of why such a large number of young people choose the medical profession and explain how their feelings develop throughout the course are essential to plan and adjust their training. For that purpose, the main objective of this study was to point out the reasons why students from the $1^{\text {st }}$ to the $12^{\text {th }}$ semesters of the medical course, attending a medical school, chose Medicine as their profession and to identify their concerns about the employment perspective.

\section{METHOD}

Considering the nature of the data, the present investigation is a quantitative and documentary one. As for the objectives, it is a descriptive study, and as for the information sources and the collection procedures, it is a documental research. The sample consists of 308 students from the $1^{\text {st }}$ to the $12^{\text {th }}$ semesters of the medical course at UNOESC - of a total of 372 - to which questionnaires were applied, from July to November 2018, containing seven questions, addressing the reasons that lead the students to choose Medicine as a profession, concerns about the future after graduation, the way they want to exercise their profession, difficulties they expect to find in their professional practice and characteristics they consider important for the medical profession, in addition to a questionnaire containing sociodemographic questions. The topics of the questions were organized based on the answers to diagnostic questionnaires applied to 226 students attending the $4^{\text {th }}$ and $7^{\text {th }}$ semesters, in the disciplines of Ethics and Society (Bioethics) and Medical Ethics, between the years 2013 and 2018. The data were stored in an Excel spreadsheet and later submitted to statistical analysis through the Fischer Exact tests and the Chi-square test, being specially analyzed the difference in the perception of students in the preinternship cycles, whose duration is 3.5 years, from the $1^{\text {st }}$ to the $7^{\text {th }}$ semesters $(n=207 ; 67.21 \%)$ and internship, whose duration is 2.5 years, from the $8^{\text {th }}$ to the $12^{\text {th }}$ semesters $(n=101 ; 32.79 \%)$.

\section{RESULTS}

Regarding the sociodemographic characteristics, there was a predominance of females, with $63.31 \%$ (195) of the participants, of which 6 did not specify any option, but without a significant difference between the groups $(p=0.4586)$. The age group that answered the highest number of questions was 22 26 years old, with 155 (50.32\%) answers, followed, respectively, by the 16-21 year old groups, with $128(41.56 \%)$, and 27 years old or older, with $16(5.19 \%)$, whereas 9 individuals did not inform their age.

The majority declared having a family income of 4 to 10 minimum wages ( $n=118 ; 38.31 \%$ ), followed by 10 to 20 minimum wages $(n=103 ; 33.44 \%)$ and the minority more than 20 minimum wages $(n=44 ; 14.28 \%)$. There were eleven participants (3.57\%) in the range of two minimum wages and $27(8.77 \%)$ in the range of 2 to 4 ; five participants did not answer about their family income. There was no significant difference in the income distribution between the groups $(p=0.1736)$. 
When asked about the main reason for choosing Medicine as a future profession, with their being able to mark more than one option, the following order of frequency of answers was obtained: "Altruism" (71.75\%), "Financial stability / Good salary / Good financial return" (59.42\%) and "Personal accomplishment" (58.77\%), as shown in Table 1. When the phases were grouped, there was a significant decrease during the internship of the answers "Altruism" ( $p$ <.01), "Opportunity to deal with or have contact with people" $(p<0.01)$ and "Scientific curiosity / Search for human knowledge" ( $p<0.05)$.

Regarding the future, after graduation, the main concern was "Doing a good job / Being a good professional" (79.87\%), followed by "Pass the residency exam" / "Obtaining qualification" (64.29\%) and "Fear of making mistakes / Responsibilities of the profession" (52.27\%), as shown in Table 2.

Regarding the postgraduate period, $7.79 \%$ expressed the intention to continue as non-specialist, general practitioners and $92.21 \%$ as specialist physicians. When comparing the

Table 1. Reasons for choosing the medical course.

\begin{tabular}{|c|c|c|c|c|}
\hline & Total & Pre-internship & Internship & \\
\hline \multirow[t]{2}{*}{ Questions related to the choice of profession } & $\%(n)$ & $\%(n)$ & $\%(n)$ & \multirow[t]{2}{*}{$\mathbf{P}$} \\
\hline & $100(308)$ & $67.21(207)$ & $32.79(101)$ & \\
\hline Financial stability / Good salary / Good financial return & $59.42(183)$ & $60.39(125)$ & $57.43(58)$ & 0.6234 \\
\hline $\begin{array}{l}\text { Status / Prestige or social recognition of the physician or } \\
\text { medicine }\end{array}$ & $4.55(14)$ & $5.31(11)$ & $2.97(3)$ & 0.5249 \\
\hline Opportunity to deal with or have contact with people & $36.36(112)$ & $41.55(86)$ & $25.74(26)$ & ** \\
\hline Family or third-party influence, personal or family illness & $15.91(49)$ & $14.98(31)$ & $17.82(18)$ & 0.5120 \\
\hline $\begin{array}{l}\text { Love / Admiration for the profession or for medical } \\
\text { professionals }\end{array}$ & $51.95(160)$ & $55.56(115)$ & $44.55(45)$ & 0.0887 \\
\hline Challenging course or university admission exam & $8.44(26)$ & $8.21(17)$ & $8.91(9)$ & 0.8297 \\
\hline
\end{tabular}

The values show the relative and absolute frequencies for the evaluated questions. Fisher's exact test was used. The statistical difference between the pre-internship and internship groups was considered significant when ${ }^{*} p<0.05$ and ${ }^{* *} p<0.01$.

Source: Created by the authors.

Table 2. Concerns after graduation.

\begin{tabular}{|c|c|c|c|c|}
\hline \multirow{3}{*}{$\begin{array}{c}\text { Questions related to concern about the future after } \\
\text { graduation }\end{array}$} & Total & Pre-internship & Internship & \multirow{3}{*}{$\mathbf{P}$} \\
\hline & $\%(n)$ & $\%(n)$ & $\%(n)$ & \\
\hline & $100(308)$ & $67.21(207)$ & $32.79(101)$ & \\
\hline Choosing the right specialty & $38.64(119)$ & $35.75(74)$ & $44.55(45)$ & 0.1701 \\
\hline $\begin{array}{l}\text { Pass the residency exam / obtaining qualification / } \\
\text { having sufficient knowledge }\end{array}$ & $64.29(198)$ & $61.84(128)$ & $69.31(70)$ & 0.2081 \\
\hline Doing a good job / being a good professional & $79.87(246)$ & $83.06(174)$ & $71.29(72)$ & * \\
\hline Keeping up-to-date / improving knowledge & $44.48(137)$ & $44.93(93)$ & $43.56(44)$ & 0.9028 \\
\hline Job market / devaluation of the profession & $34.42(106)$ & $28.02(58)$ & $47.52(48)$ & $* * *$ \\
\hline $\begin{array}{l}\text { Fear of making mistakes and the responsibilities of the } \\
\text { profession }\end{array}$ & $52.27(161)$ & $53.14(110)$ & $50.50(51)$ & 0.7159 \\
\hline Time to balance one's career and personal life & $37.99(117)$ & $42.51(88)$ & $28.71(29)$ & * \\
\hline Poor infrastructure to practice the profession & $17.86(55)$ & $18.36(38)$ & $16.83(17)$ & 0.8742 \\
\hline Public policies related to health & $23.05(71)$ & $22.22(46)$ & $24.75(25)$ & 0.6661 \\
\hline
\end{tabular}

The values show the relative and absolute frequencies for the evaluated questions. Fisher's exact test was used. The statistical difference between the pre-internship and internship groups was considered significant when ${ }^{*} p<0.05$ and ${ }^{* *} p<0.01$.

Source: Created by the authors. 
cycles, $89.86 \%$ of the pre-internship students and $97.03 \%$ of the internship students chose to become a specialist doctor $(p<0.05)$. Among the specialties, the most sought after was gynecology and obstetrics (6.17\%), followed by pediatrics (4.55\%), general surgery (4.22\%), psychiatry (3.57\%) and oncology (3.25\%), according to Table 3.

Table 3. Choice of specialty.

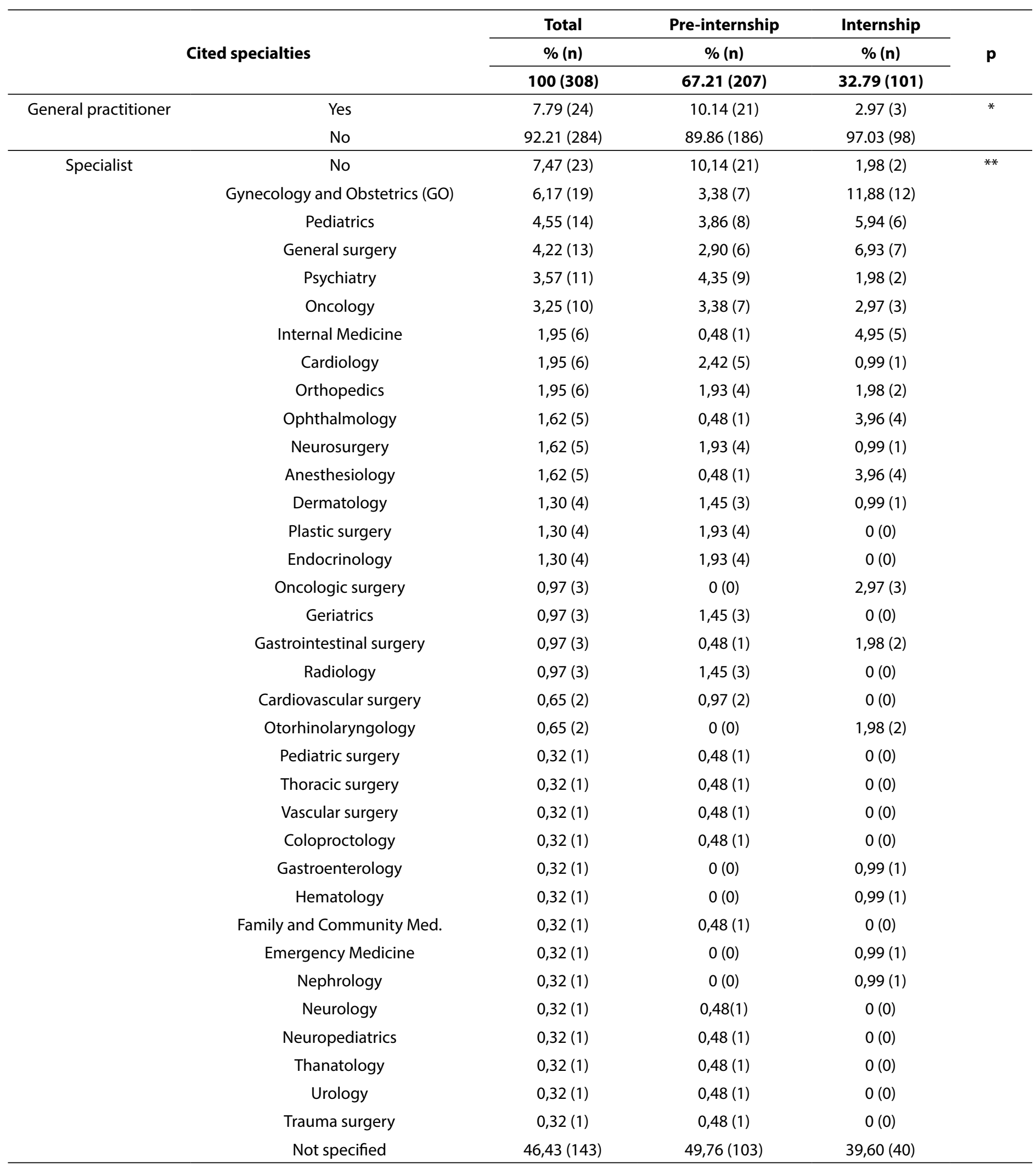

The values show the relative and absolute frequencies for the evaluated questions. Fisher's exact test was used for the qualitative variable "General Practitioner" and Pearson's Chi-square test was used for the qualitative variable "Specialist". The statistical difference between the pre-internship and internship groups was considered significant when ${ }^{*} p<0.05$ and ${ }^{* *} p<0.001$.

Source: Created by the authors. 
Regarding the way of exercising the profession, the majority (51.30\%) expressed a desire to work in public or private service. Among the pre-internship students, 59.9\% wanted to work in public or private service. During the internship cycle, $64.36 \%$ wanted to work as a self-employed professional.

Among the difficulties they expect to face as physicians, the majority (57.7\%) considered "Competition" (Table 4). This variable showed an " $n$ " of 0.0848 higher due to the option of marking more than one answer.

The students were asked to comment on some aspects of medical practice, classifying them as "Very important", "Not very important" or "Not important at all". The "Very important" items related to "Medicine as a means to be useful or to help people" stands out, chosen by $98.38 \%$ of the participants, and "Means to acquire scientific knowledge", by $83.12 \%$ and "A means to acquire humanistic knowledge", by $82.14 \%$ (Table 5).

Regarding the feelings experienced as a medical student, the students quantified 8 aspects as "Very important", "Not very important" or "Not important at all" (Table 6). "Very important" were considered "Level of anxiety" (80.52\%), 'Level of stress" (79.55\%), "Sense of overload' (73.38\%), "Insecurity about the future" (57.14\%), "Financial problems" (40.58\%) and "Concerns about the excess of medical schools" (53.90\%). There was a significant difference between the responses of the groups in relation to "Insecurity about the future" due to the higher level of concern expressed by the internship students $(p<0.05)$.

Table 4. How you want to practice the profession and its expected difficulties.

\begin{tabular}{|c|c|c|c|c|c|}
\hline \multirow{3}{*}{$\begin{array}{l}\text { Questions related to the } \\
\text { future after graduation }\end{array}$} & \multirow{3}{*}{ Answers } & Total & Pre- internship & Internship & \multirow{3}{*}{$\mathbf{P}$} \\
\hline & & $\%(n)$ & $\%(\mathrm{n})$ & $\%(n)$ & \\
\hline & & $100(308)$ & $67.21(207)$ & $32.79(101)$ & \\
\hline \multirow{3}{*}{$\begin{array}{l}\text { How you want to practice } \\
\text { the profession }\end{array}$} & Public or private service & $51.30(158)$ & $59.90(124)$ & $33.66(34)$ & $* *$ \\
\hline & Liberal professional & $4.55(14)$ & $2.90(6)$ & $7.92(8)$ & 0.0759 \\
\hline & Self-employed professional & $55.52(171)$ & $51.21(106)$ & $64.36(65)$ & * \\
\hline \multirow{4}{*}{ Main expected difficulties } & Competition & $57.70(205)$ & $61.7(145)$ & $50.0(60)$ & \multirow{4}{*}{0.0848} \\
\hline & Salary & $11.50(41)$ & $8.90(21)$ & $16.70(20)$ & \\
\hline & Unemployment & $13.20(47)$ & $12.30(29)$ & $15.0(18)$ & \\
\hline & Others & $17.50(62)$ & $17.0(40)$ & $18.30(22)$ & \\
\hline
\end{tabular}

The values show the relative and absolute frequencies for the evaluated questions. Fisher's exact test was used for the qualitative variables "Public or private service", "Liberal Professional" and "Self-employed professional", and for the qualitative variable "Main expected difficulties", Pearson's Chi-square test was used. The statistical difference between the pre-internship and internship groups was considered significant when ${ }^{*} p<0.05$ and ${ }^{* *} p<0.001$.

Source: Created by the authors.

Table 5. Importance of Medicine in the exercise of the profession.

\begin{tabular}{|c|c|c|c|c|c|}
\hline \multirow{3}{*}{$\begin{array}{l}\text { Questions related to the practice } \\
\text { of the medical profession }\end{array}$} & \multirow{3}{*}{ Answers } & Total & Pre-internship & Internship & \multirow{3}{*}{$\mathbf{P}$} \\
\hline & & $\%(n)$ & $\%(n)$ & $\%(n)$ & \\
\hline & & $100(308)$ & $67.21(207)$ & $32.79(101)$ & \\
\hline As a means to help people & A lot & $98.38(303)$ & $99.03(205)$ & $97.03(98)$ & 0.3352 \\
\hline \multirow{2}{*}{ Financial stability } & A little & $23.05(71)$ & $27.05(56)$ & $14.85(15)$ & \multirow{2}{*}{$*$} \\
\hline & Not at all & $0.65(2)$ & $0.97(2)$ & $0(0)$ & \\
\hline \multirow{3}{*}{ Social status } & $\begin{array}{c}\text { A little } \\
\text { A lot }\end{array}$ & $\begin{array}{c}47.40(146) \\
2.92(9)\end{array}$ & $\begin{array}{c}45.41(94) \\
1.93(4)\end{array}$ & $\begin{array}{c}51.49(52) \\
4.95(5)\end{array}$ & \multirow{3}{*}{0.2417} \\
\hline & Not at all & $49.03(151)$ & $52.17(108)$ & $42.57(43)$ & \\
\hline & Not specified & $0.65(2)$ & $0.48(1)$ & $0.99(1)$ & \\
\hline
\end{tabular}


Table 5. (Continuation) Importance of Medicine in the exercise of the profession.

\begin{tabular}{|c|c|c|c|c|c|}
\hline \multirow{3}{*}{$\begin{array}{l}\text { Questions related to the practice } \\
\text { of the medical profession }\end{array}$} & \multirow{3}{*}{ Answers } & Total & Pre-internship & Internship & \multirow{3}{*}{$\mathbf{P}$} \\
\hline & & $\%(n)$ & $\%(n)$ & $\%(n)$ & \\
\hline & & $100(308)$ & $67.21(207)$ & $32.79(101)$ & \\
\hline \multirow{2}{*}{$\begin{array}{l}\text { Acquisition of scientific } \\
\text { knowledge }\end{array}$} & A lot & $83.12(256)$ & $82.13(170)$ & $85.15(86)$ & \multirow{2}{*}{0.3715} \\
\hline & Not at all & $0.32(1)$ & $0.48(1)$ & $0(0)$ & \\
\hline \multirow{3}{*}{$\begin{array}{l}\text { Acquisition of humanistic } \\
\text { knowledge }\end{array}$} & A little & $16.88(52)$ & $15.46(32)$ & $19.80(20)$ & \multirow{3}{*}{0.6344} \\
\hline & A lot & $82.14(253)$ & $83.57(173)$ & $79.21(80)$ & \\
\hline & Not at all & $0.97(3)$ & $0.97(2)$ & $0.99(1)$ & \\
\hline Opportunity to deal with people & A little & $17.86(55)$ & $14.49(30)$ & $24.75(25)$ & * \\
\hline
\end{tabular}

The values show the relative and absolute frequencies for the evaluated questions. Fisher's exact test was used for the qualitative variable "As a means to help people", whereas Pearson's chi-square test was used for the other qualitative variables. The statistical difference between the preinternship and internship groups was considered significant when " $p<0.05$.

Source: Created by the authors.

Table 6. Feelings experienced during the medical course.

\begin{tabular}{|c|c|c|c|c|c|}
\hline \multirow{3}{*}{$\begin{array}{l}\text { Questions related to current } \\
\text { feelings experienced during the } \\
\text { course }\end{array}$} & \multirow{3}{*}{ Answers } & Total & Pre-internship & Internship & \multirow{3}{*}{$p$} \\
\hline & & $\%(n)$ & $\%(n)$ & $\%(n)$ & \\
\hline & & $100(308)$ & $67.21(207)$ & $32.79(101)$ & \\
\hline \multirow{2}{*}{ Anxiety level } & A lot & $80.52(248)$ & $77.78(161)$ & $86.14(87)$ & \multirow{2}{*}{0.3494} \\
\hline & Not at all & $2.92(9)$ & $3.38(7)$ & $1.98(2)$ & \\
\hline \multirow{4}{*}{ Stress level } & A little & $18.51(57)$ & $15.94(33)$ & $23.76(24)$ & \multirow{4}{*}{0.3271} \\
\hline & A lot & $79.55(245)$ & $81.64(169)$ & $75.25(76)$ & \\
\hline & Not at all & $1.62(5)$ & $1.93(4)$ & $0.99(1)$ & \\
\hline & Not specified & $0.32(1)$ & $0.48(1)$ & $0(0)$ & \\
\hline \multirow{2}{*}{ Dissatisfaction level } & A little & $56.49(174)$ & $52.66(109)$ & $64.36(65)$ & \multirow{2}{*}{0.0583} \\
\hline & Not specified & $0.65(2)$ & $0.97(2)$ & $0(0)$ & \\
\hline \multirow{4}{*}{ Feeling of overload } & A little & $24.35(75)$ & $24.64(51)$ & $23.76(24)$ & \multirow{4}{*}{0.7696} \\
\hline & A lot & $73.38(226)$ & $72.95(151)$ & $74.26(75)$ & \\
\hline & Not at all & $1.62(5)$ & $1.45(3)$ & $1.98(2)$ & \\
\hline & Not specified & $0.65(2)$ & $0.97(2)$ & $0(0)$ & \\
\hline \multirow{4}{*}{ Feeling insecure about the future } & A little & $35.71(110)$ & $39.61(82)$ & $27.72(28)$ & \multirow{4}{*}{ * } \\
\hline & A lot & $57.14(176)$ & $51.69(107)$ & $68.32(69)$ & \\
\hline & Not at all & $6.82(21)$ & $8.21(17)$ & $3.96(4)$ & \\
\hline & Not specified & $0.32(1)$ & $0.48(1)$ & $0(0)$ & \\
\hline
\end{tabular}


Table 6. (Continuation) Feelings experienced during the medical course.

\begin{tabular}{|c|c|c|c|c|c|}
\hline \multirow{3}{*}{$\begin{array}{l}\text { Questions related to current } \\
\text { feelings experienced during the } \\
\text { course }\end{array}$} & \multirow{3}{*}{ Answers } & Total & Pre-internship & Internship & \multirow{3}{*}{$\mathrm{p}$} \\
\hline & & $\%(n)$ & $\%(n)$ & $\%(n)$ & \\
\hline & & $100(308)$ & $67.21(207)$ & $32.79(101)$ & \\
\hline \multirow{4}{*}{ Financial problems } & A little & $50.0(154)$ & $46.38(96)$ & $57.43(58)$ & \multirow{4}{*}{0.2697} \\
\hline & A lot & $40.58(125)$ & $43.96(91)$ & $33.66(34)$ & \\
\hline & Not at all & $9.09(28)$ & $9.18(19)$ & $8.91(9)$ & \\
\hline & Not specified & $0.32(1)$ & $0.48(1)$ & $0(0)$ & \\
\hline \multirow{4}{*}{$\begin{array}{l}\text { Questions about the quality of } \\
\text { education }\end{array}$} & A little & $44.16(136)$ & $42.03(87)$ & $48.51(49)$ & \multirow{4}{*}{0.5008} \\
\hline & A lot & $41.23(127)$ & $41.55(86)$ & $40.59(41)$ & \\
\hline & Not at all & $14.29(44)$ & $15.94(33)$ & $10.89(11)$ & \\
\hline & Not specified & $0.32(1)$ & $0.48(1)$ & $0(0)$ & \\
\hline \multirow{4}{*}{$\begin{array}{l}\text { Concerns about the excess of } \\
\text { medical schools }\end{array}$} & A little & $35.71(110)$ & $32.85(68)$ & $41.58(42)$ & \multirow{4}{*}{0.0572} \\
\hline & A lot & $53.90(166)$ & $53.62(111)$ & $54.46(55)$ & \\
\hline & Not at all & $10.06(31)$ & $13.04(27)$ & $3.96(4)$ & \\
\hline & Not specified & $0.32(1)$ & $0.48(1)$ & $0(0)$ & \\
\hline
\end{tabular}

The values show the relative and absolute frequencies for the evaluated questions. The statistical difference between the pre-internship and internship groups was considered significant when ${ }^{*} p<0.05$.

Source: Created by the authors.

\section{DISCUSSION}

The tendency towards a higher number of women in the medical course was confirmed in this study (63.3\%), in agreement with the results of two other studies in which, respectively, $74.4 \%$ and $53 \%$ of the participants were women ${ }^{10,11}$. The observed results follow a global trend, since, as of 1970, colleges and universities started to show a greater participation of women, an aspect that gradually increased in the following two decades and more rapidly in the first decade of the $21^{\text {st }}$ century ${ }^{12}$.

Regarding the main reason that led the participants to choose Medicine as a profession, the most relevant result was 'Altruism" (71.75\%), followed by "Financial stability" (59.4\%) and "Personal accomplishment" (59\%), as shown in Table 1, data that are partially in agreement with another study in which the determining factor for the choice of the profession was "Helping and serving people" or "Working with people", followed by "Employability" and "Good salaries". Vocation or affinity with the profession showed a lower preference (54.2\%), as demonstrated in another study in which the authors found a similar rate for the answer "Identification with the medical profession" (53.4\%), an option that covered both vocation and personal accomplishment ${ }^{13}$.

When comparing the responses of pre-internship and internship students, on the one hand, there was a significant decrease in the option for "Altruism". On the other hand, the concern with "Financial stability" increased, similar to a study carried out in 2011 in which "Employability", "Insertion in the labor market" and "Possibility of good salaries" were frequent justifications for the choice of Medicine as a profession ${ }^{8}$.

Therefore, students enter the undergraduate medical course with the main concept of altruism; however, with the knowledge of the problems in the labor market, they wake up to the Brazilian medical situation, disbelieving the generous financial return and reducing their concerns for the others. However, the principle of beneficence, which in part represents altruism, was incorporated into the practice of Medicine since its beginning through the Hippocratic Oath and, since the last century, it has become the Fundamental Principle I of the Brazilian Code of Medical Ethics ${ }^{10,14}$. Therefore, although the reality of the profession can discourage altruism, this quality is inherent to the medical profession and essential to provide greater benefit to patients and should be preserved.

The participants from a medical school elected humanism, affinity and social status as the three main motivators for choosing the profession, showing that students, in addition to altruism and vocation, may be fascinated by the financial return and social relevance of the profession ${ }^{15}$. In the present study, the participants expressed concerns about their future salary at a rate that ranged from $8.9 \%$ in the preinternship, to $16.7 \%$ in the internship period (Table 2 ), showing that being close to start practicing the profession contributes to the better perception of the economic aspect. This reality was evident in an editorial published by the Regional Council of Medicine of the State of São Paulo (CREMESP Conselho Regional de Medicina do Estado de São Paulo), which 
highlighted the issue of degrading salaries for public service physicians, which unfavorably reflect on the private sector, a trend that occurs in disregard of the almost ten thousand hours/class during undergraduate medical school, without considering the time spent with the pre-university admission exam and specialization ${ }^{16}$.

A commonly mentioned concern by both groups was unemployment $(13.2 \%$ in the pre-internship and $15 \%$ in the internship periods), corroborating another study in which the excess of medical schools in Brazil and projections indicating that, in four decades, the country will have about 1.5 million medical professionals, constituted reasons for the students' apprehension $^{8}$. The excess of medical schools is added to the competition that will take place due to the thousands of students studying Medicine in neighboring countries and who will seek to join the national labor market.

Regarding the choice of specialties (Table 3), there was an increase in preference for gynecology and obstetrics, pediatrics, general surgery, psychiatry and oncology. The preference may vary according to the students' gender, as shown by a survey in which women preferred specialties such as Gynecology and Obstetrics (GO), Pediatrics and Palliative Care, inferring that this occurs because they have greater empathy, listening skills and affection, qualities that are common to their maternal nature, which led them to be less frequently the target of lawsuits in the Medical Council ${ }^{17}$. In the present study, although it is one of the most reported for medical errors ${ }^{18}$, there was also a disproportionate preference for the specialty of gynecology and obstetrics by women, but no participant chose palliative care. There seems to be no doubt that the professional career and family construction are taken into account at the time of the choice of specialty, a concern expressed by $37.99 \%$ of the participants who aspired to reconcile career and personal life after graduation.

Almost all participants considered their level of anxiety $(80.52 \%)$ and stress $(79.55 \%)$ to be very important. The medical course requires intense dedication and availability of time from the student to fulfill their dream of becoming a physician. In a study carried out with students from a medical course, it was found that, during training, stressful moments are present, which are potentially harmful to the psychological component ${ }^{4}$. This was also evident in another study in which $78 \%$ of students stated that Medicine is stressful, with an excessive workload and working long hours, resulting in less time available for family and leisure ${ }^{19}$. Moreover, the fact that students rarely seek help with their problems results in personal and professional losses, as well as negatively influencing the choice of the intended specialty and the future confrontation of mistakes made during the performance ${ }^{20}$.
Another noteworthy result found in the present study was the lower willingness expressed by internship students to pursue a career as general practitioners, non-specialists (Table 4). This fact was also observed in a study carried out at the UFMG School of Medicine, in which only $15.4 \%$ of the more than 700 interviewed students stated that they would like to work in primary health care and, among those who considered becoming general practitioners, none was attending the last semester of the course ${ }^{17}$. This aspect can be explained by the result of another survey in which $73.6 \%$ of the students believed that general practitioners have lower remuneration and $89.3 \%$ have lower social prestige ${ }^{21}$.

According to data from Medical Demography in Brazil for 2018 , of all active medical licenses in the country in the previous year, $62.5 \%$ had one or more Medical Specialist titles, with a ratio of 1.67 specialist for each generalist ${ }^{22}$. Most medical schools have maintained their curriculum centered on specialties, an aspect that is associated with the precariousness of the Brazilian Unified Health System (SUS - Sistema Único de Saúde) service structure, where general practitioners work, contributing to the demotivation ${ }^{23}$. Therefore, when considering the less favorable conditions, the low salary and the instability of the public health system, most students prefer work alternatives that do not include this option ${ }^{13}$. Therefore, passing the residency exam and obtaining professional qualification has reached a high rate in the preference of the participants of the present study.

Medicine is a profession aimed at providing benefits to human health and should be performed without distinction and with the greatest possible commitment ${ }^{14}$. In this aspect, it was evident that, for almost all participants, Medicine is a means to help people (Table 5). However, the fear of making mistakes and of the devaluation of the profession, as well as the level of responsibility were noteworthy in both groups (Table 2 ), as the possibility of being the target of a lawsuit is real, as occurred with 613 physicians who were judged by the Regional Council of Medicine of the State of Santa Catarina from 2004 to $2009^{18}$.

\section{CONCLUSIONS}

The main reasons that led the students to choose Medicine as a profession were altruism and financial stability. However, when comparing the responses of students at the beginning and end of the course, there was a decrease in the preference for altruism during the internship period, probably due to greater knowledge of the reality of professional practice by this group. However, the perception of the practice of Medicine as a means to help people remained high in both groups.

Regarding the employment perspective, the fear of the labor market limitation and the devaluation of the profession emerged. The indiscriminate opening of medical schools in the 
country may be inducing students to worry about their careers, as most of them considered this aspect to be very important.

Almost all participants, especially from those attending the internship, expressed the desire to take specialization courses, a preference that is justified by the structural, technical and salary limitations of the public sector, which constitutes the main employment opportunity for general practitioners, who are not specialists. The increase in anxiety and insecurity that occurs in the final semesters of the course matches the fear of not being able to get a job and not being a good professional.

In conclusion, students have a more idealized view of Medicine in the early periods of medical school, but students attending the last semesters of the course showed a decrease in the humanistic ideals that motivated the choice of the profession and an increase in the insecurity related to the job market, to the salary and the achievement of professional success.

\section{AUTHORS' CONTRIBUTION}

\section{Eduardo Delatorre Kamijo and Maria Victória Schweder de} Lima participated in the research design, data collection, data analysis and writing of the manuscript. Ana Paula Pereira participated in the research design, data analysis and final review of the manuscript. Elcio Luiz Bonamigo participated as a researcher and advisor in all stages of the study, including the writing and final review of the manuscript.

\section{CONFLICTS OF INTEREST}

The authors declare no conflicts of interest.

\section{SOURCES OF FUNDING}

The authors declare no sources of funding.

\section{REFERENCES}

1. Ramos-Cerqueira ATA, Lima MCP. A formação da identidade do médico: implicações para o ensino de graduação em Medicina. Interface. 2002;6(11):107-16. doi: 10.1590/S1414-32832002000200008

2. Diretório das Escolas de Medicina. Painel de indicadores. 2020 [access in 16 feb 2021]. Available from: https://produtos.direm.org/painel

3. Millan LR, Azevedo RS, Rossi E, De Marco OLN, Millan MPB, Arruda $P C V$. What is behind a student's choice for becoming a doctor? Clinics. 2005;60(2):143-50. doi: 10.1590/S1807-59322005000200011.

4. Santos FS, Maia CRC, Faedo FC, Gomes GPC, Nunes ME, Oliveira MVM. Estresse em estudantes de cursos preparatórios e de graduação em Medicina. Rev Bras Educ Med. 2017;41(2):194-200. doi: 10.1590/1981-52712015v41n2rb20150047.

5. Aragao JCS, Rossi HR, Casiraghi B. A jornada do acadêmico de Medicina: um modelo simbólico da formação médica. Rev Bras Educ Med. 2018;42(1):40-6. doi: 10.1590/1981-52712018v42n1rb20170037.

6. Miranda IMM, Tavares HHF, Silva HRS, Braga MS, Santos RO, Guerra HS. Qualidade de vida e graduação em Medicina. Rev Bras Educ Med. 2020;44(3):1-8. doi: 10.1590/S0100-55022020000300206.
7. Kam SXL, Toledo ALS, Pacheco CC, Souza GFB, Santana VLM, Bonfá-Araujo, $B$ et al. Estresse em estudantes ao longo da graduação médica. Rev Bras Educ Med. 2020;43(1):247-53. doi: 10.1590/S0100-55022019000500246.

8. Ribeiro MMF, Leal SS, Diamantino FC, Bianchi HA. A opção pela medicina e os planos em relação ao futuro profissional de estudantes de uma faculdade pública brasileira. Rev Bras Educ Med. 2011;35(3):405-11. doi: 10.1590/S0100-55022011000300015.

9. Barreto MA, Reis CN, Miranda IB, Jardim LCR, Teixeira MP. Ser médico: o imaginário coletivo de estudantes de medicina acerca da profissão de médico. Cadernos Unifoa. 2017;4(11):73-6.

10. Monteiro MFA, Barbosa JMO, Carteado EMF, Ferreira MAD, André AM Opção pelo curso de Medicina em Angola: o caso da Universidade Agostinho Neto. Rev Bras Educ Med. 2010;34(3):346-54. doi: 10.1590/ S0100-55022010000300003.

11. Moreira SNT, Silva CAN, Tertulino FF, Tertulino FMF, Vilar MJP, Azevedo GD. Processo de significação de estudantes do curso de medicina diante da escolha profissional e das experiências vividas no cotidiano acadêmico. Rev Bras Educ Med. 2006;30(2):14-9. doi: 10.1590/S010055022006000200003.

12. Avila RC. Formação das mulheres nas escolas de medicina. Rev Bras Educ Med. 2014; 38(1):142-9 [access in 18 sep 2019]. Available from: https:// www.scielo.br/pdf/rbem/v38n1/19.pdf.

13. Ferreira RA, Peret Filho LA, Goulart EMA, Valadão MMA. O estudante de medicina da Universidade Federal de Minas Gerais: perfil e tendências. Rev Assoc Med Bras. 2000;46(3):224-31. doi: 10.1590/S010442302000000300007.

14. Conselho Federal de Medicina. Resolução $n^{\circ} 2.217$, de 27 de setembro de 2018. Brasília; CFM; 2018.

15. Trindade LMDF, Vieira MJ. Curso de Medicina: motivações e expectativas de estudantes. Rev Bras Educ Med. 2009;33(4):542-54. doi: 10.1590/S01005502200900040000 .

16. Conselho Regional de Medicina do Estado de São Paulo. Salários dos médicos no serviço público: ultraje. São Paulo: Cremesp; 2008 [access in 16 may 2019]. Available from: https://www.cremesp.org. $\mathrm{br} /$ ?siteAcao $=$ Jornal\&id $=946$.

17. Lempp $\mathrm{H}$, Seale $\mathrm{C}$. Medical students' perceptions in relation to ethnicity and gender: a qualitative study. BMC Med Educ. 2006;17(6):1-7. doi: 10.1186/1472-6920-6-17.

18. Koeche LG, Cenci I, Bortoluzzi MC, Bonamigo EL. Prevalência de erro médico entre as especialidades médicas nos processos julgados pelo Conselho Regional de Medicina do Estado de Santa Catarina. ACM Arq Catarin Med. 2013;45(4):45-53.

19. Saad SMA, Fatima SS, Faruqi AA. Students' views regarding selecting medicine as a profession. J Pak Med Assoc. 2011;61(8):832-6.

20. Maia HAAS, Assunção ACS, Silva CS, Santos JLP, Menezes CJJ, Bessa Jr J. Prevalência de sintomas depressivos em estudantes de Medicina com currículo de aprendizagem baseada em problemas. Rev Bras Educ Med. 2020;44(3):1-7. doi: 10.1590/\$0100-55022020000300219.

21. Chehuen Neto JA, Sirimarco MT, Cândido TC, Ulhoa CM, Reis BP, Lima VM Formação médica generalista: percepção do profissional e do estudante. HU Rev. 2014;40(1-2):13-23 [access in 5 oct 2021]. Available from: https:// periodicos.ufff.br/index.php/hurevista/article/view/2095.

22. Scheffer $M$, coordenador. Demografia médica no Brasil 2018. São Paulo: FMUSP, CFM, Cremesp; 2018.

23. Silva LO, Melo IB, Teixeira LAS. Interface entre oferta de vagas de residência médica, demanda por médicos especialistas e mercado de trabalho. Rev Bras Educ Med. 2020;43(1):119-26. doi: 10.1590/S010055022020000300219 . 